Bangladesh J. Sci. Ind. Res. 42(3), 317-326, 2007

\title{
Studies on the Preservation of Raw Cow's Milk by Chemical Method
}

\author{
F. Rokhsana, U. K. Das, R. Yeasmin, A. Nahar and S. Parveen \\ Institute of Food Science and Technology Bangladesh Council \\ of Scientific and Industrial Research Qudrat-e-Khuda Road, \\ Dhanmondi, Dhaka-1205, Bangladesh.
}

\begin{abstract}
Studies carried out to develop a technique for the preservation of cow's milk in raw condition using hydrogen peroxide $\left(\mathrm{H}_{2} \mathrm{O}_{2}\right)$ as a preservative. Fresh cow's milk was collected and experiments were conducted by four treatments in order to achieve the optimum condition of storage. The treatments were with various concentration of $\mathrm{H}_{2} \mathrm{O}_{2}$ starting from $0.05 \%, 0.1 \%, 0.2 \%, 0.3 \%, 0.4 \%$, \& $0.5 \%$. Treated milk with $0.05 \%$ concentration of $\mathrm{H}_{2} \mathrm{O}_{2}$ had storage period of 20 days compared to that of the control one (5 days only) in refrigerated temperature $\left( \pm 8^{\mathrm{O}} \mathrm{C}\right)$. On the other hand hydrogen peroxide treated milk ( $0.05 \%)$ had a storage period of 8 hours at room temperature $\left( \pm 28^{\mathrm{O}} \mathrm{C}\right)$. Results also showed that the higher concentration of $\mathrm{H}_{2} \mathrm{O}_{2}$ had no effect on storage period than that of control. Milk products like kheer and halawa prepared by treated milk and stored for 20 days showed almost nil growth of total coliform and E. coli which means that food products prepared from hydrogen peroxide treated milk is safe for human consumption.
\end{abstract}

Key words : Raw, Storage, Hydrogen peroxide, Preservative, keeping quality, Pasteurization, deteriorated, MPN.

\section{Introduction}

Milk is a food of high nutritious value. It phosphorous and riboflavin, one third of promotes growth and maintenance of body vitamin A, ascorbic acid, and thiamine, one tissue. It is reported that daily consumption fourth of the calories, and with the exception of one liter of cow's milk furnishes an aver- of iron, copper, manganese and magnesium, age man approximately all the fat, calcium, all the minerals needed daily (Sayem 1998). 
Raw milk is a perishable item. To preserve this nutritious drink for marketing is a problem for milk trader. The milk trader often fails to maintain its keeping quality after procurement of milk in raw condition from rural area to bring it to urban area. They use some local techniques to preserves cow's milk in raw condition during transportation by putting water hyacinth leaves and date leaves etc. in milk. But this technique does not give satisfactory results and also makes the quality of milk in an unhygienic condition Sometimes this technique brings changes in the quality of milk in raw condition which makes it unsuitable for consumption. About 608 thousand metric tones of liquid milk is consumed in Bangladesh per year (Statistical year book of Bangladesh 1998). But marketing of some portion of this milk is difficult because expensive pasteurizations techniques are not available in remote area of Bangladesh. As a result a lot of milk is deteriorated during transportation.

Sometime it is observed that milk in raw condition is deteriorated within 2 or 3 days even after storing in refrigerator. In view of these facts attempts have been taken to develop a method for preservation of cow's milk in raw condition for maintaining its keeping quality Morris found that a concentration of $0.03 \%$ hydrogen peroxide for 20 minutes heat was needed to destroy salmollena typhosa (Murris, 1948). The Food and Agriculture
Organization of the United Nations recommends that under certain circumstances hydrogen peroxide may be used to improve the keeping quality of milk (Food and Agriculture Organization, United Nations 1954). The use of hydrogen peroxide method does not exclude the necessity of pasteurization of milk before human consumption (Food Laboratory News Letter 1987). Much investigation has shown that under certain condition hydrogen per oxide may be used as an acceptable preservative (Rosell, 1961). J.C.T Vendor Berg (Venden Berg, 1985) has mentioned that preservatives may be added to enhance the keeping quality of milk. Hydrogen peroxide is the most familiar one. It is destroyed by heat treatment (Venden Berg, 1985). The addition of hydrogen peroxide to milk within 1 hour of milking is recommended. It is claimed that various dairy products of satisfactory quality have been made from hydrogen peroxide treated milk (Rosell et.al. 1959). Hydrogen peroxide may be used as a desirable bactericide in milk and has been suggested as a means of improving milk quality in developing countries (Jean Grindrod and Nickorson, 1967).

So it is very important to carry out research work for developing a suitable method of milk preservation for our milk traders. The present study was undertaken to preserve milk sample by chemical method. 


\section{Materials and Methods}

Fresh cow's milk was collected from rural areas around the Dhaka city and experiment was conducted in the laboratory. The experiment was divided into four treatments such as treatment $T_{1}$ (keeping raw cow's milk covered with water hyacinth), Treatment $T_{2}$ (keeping raw cow's milk at open space with occasional stirring), Treatment $\mathrm{T}_{3}$ (keeping raw cow's milk container in ice-cold water), Treatment $\mathrm{T}_{4}$ (keeping raw cow's milk with hydrogen peroxide at different concentrations).

\section{Pretreatments}

Treatment $\mathbf{T}_{\mathbf{1}}$ : $\quad$ Five hundred (500c.c) of raw cow's milk was taken in a 1 liter beaker. Fresh water hyacinth leaves with stems were dipped into raw cow's milk at room temperature $\left( \pm 28^{\circ} \mathrm{C}\right)$.

Treatment $\mathbf{T}_{2}$ : Five hundred (500c.c) of raw cow's milk was taken in a 1 liter beaker which was kept at open space with occasional stirring at open atmosphere $\left( \pm 28^{\circ} \mathrm{C}\right)$.

Treatment $\mathbf{T}_{3}$ : Five hundred (500c.c) of raw cow's milk was taken in a 1 liter beaker and the beaker was placed in a pot surrounding ice-cold water at open atmosphere.

Treatment $\mathbf{T}_{\mathbf{4}}$ : Five hundred (500c.c) of fresh raw cow's milk was kept in 6 different
1 liter capacity beaker. Hydrogen peroxide at the different concentrations $0.05 \%, 0.1 \%$, $0.2 \%, 0.3 \%, 0.4 \%$ and $0.5 \%$ was added at room temperature and storage period for each concentration was recorded to find out optimum condition.

\section{Physical observation of $0.05 \% \mathrm{H}_{2} \mathrm{O}_{2}$ treated sample and control sample}

The collected milk sample after through mixing was divided into six equal parts. The portions were treated with $0.05 \%, 0.1 \%, 0.2 \%$, $0.3 \%, 0.4 \%$ and $0.5 \%$ of hydrogen peroxide $(\mathrm{w} / \mathrm{v})$.

The sample size was 500c.c of milk for each experiment to determine the optimum concentration $\mathrm{H}_{2} \mathrm{O}_{2}$ needed for preservation. It was found that higher concentration $\mathrm{H}_{2} \mathrm{O}_{2}$ does not have any significant effect on storage period. So the minimum concentration of $\mathrm{H}_{2} \mathrm{O}_{2}$ i.e., $0.05 \%$ was selected for preserving cow's milk (Table II).

Twenty five (25) packages, each containing 100 c.c. raw cow's milk treated with $0.05 \%$ $\mathrm{H}_{2} \mathrm{O}_{2}$ was preserved at refrigerator temperature $\left( \pm 8^{\mathrm{O}} \mathrm{C}\right)$. Also15 packages of control samples, each containing 100c.c raw cow's milk was also preserved at the same refrigerator temperature $\left( \pm 8^{\mathrm{O}} \mathrm{C}\right)$. Everyday 1 package of chemically treated sample i.e. $\mathrm{H}_{2} \mathrm{O}_{2}$ treated and 1 package of control sample was 
taken out from the refrigerator. $\mathrm{pH}$ of both treated and control batch of samples were recorded by using pocket-sized $\mathrm{pH}$ meter (Hanna, Italy) and the sample were heated to boiling to observe any physical change. Milk casein separation was taken as a parameter of milk deterioration (Yapp . Nevens . 1955).

\section{Assay of Microbial Parameter}

Standard plate counts for treated samples were taken on alternate days and those for control samples were taken on each day and total coliforms and $E$ coli. were determined by the MPN procedure (American public health association, 1985).

\section{Total Aerobic Counts}

Standard plate counts were made by Pour Plate Technique (American public health Association, 1985) using nutrient agar (NA) media. In brief $1 \mathrm{ml}$ aliquots of neat and diluted samples (upto 1 in $10^{7}$ dilution) were mixed with molten nutrient agar media (prechilled at $48^{\circ} \mathrm{C}$ ) for pouring the plates. Plates were incubated overnight at $37^{\circ} \mathrm{C}$. Counts were made from the plates of appropriate dilutions resulted 30-200 cfu/plate.

\section{Estimation of Total Coliform and E.coli}

For the estimation of Total Coliform and $E$. coli MPN procedure ${ }^{11}$ was used. In brief, triplicate of $30 \mathrm{ml}, 1 \mathrm{ml}$ and $0.1 \mathrm{ml}$ portions of the samples were inoculated in lauryl tryptose broth (LST) containing inverted Durham's tube and incubated at $37^{\circ} \mathrm{C}$ for 24 to 48 hrs. Tubes were observed for the gas production. For the contamination of the coliform groups the cultures from positive LST tubes were reinoculated in brilliant green bile broth (BGLB) containing inverted durham's tube, incubated at $37^{\circ} \mathrm{C}$ for 24 to $48 \mathrm{hrs}$ and observed for the gas production. Total coliforms were estimated the BGLB positive portions of the LST tubes with MPN chart.

For the estimation of $E$. coli cultures from BGLB tubes were plated onto eosin-methylene-blue (EMB) agar plate, incubated overnight at $37^{\circ} \mathrm{C}$ and checked for the presence of metallic sheen. Typical colonies from EMB plates were grown on NA plate and used for gram-staining and $\mathrm{IMViC}$ test that constituted the completed test for $E$.coli.

\section{Chemical test}

Proximate composition of the stored sample was done at three days interval according to the standard method of analysis (A.O.A.C 1984).

\section{Method of determination}

Protein : Protein content was determined by the estimating nitrogen content of the sample 
by kjeldahl's method and multiplying the nitrogen value by 6.38 .

Moisture : It was determine by evaporating the sample on water bath to a constant weight by the standard method.

Fat : Casein on milk is precipitated by ethanol and fat was extracted with diethyl ether and petroleum ether.

Ash : Ash was determined by burning sample in a crucible until smoke is removed. Then it was burnt in the muffle furnace at $600^{\circ} \mathrm{C}$ for 6 hours.

Lactose : Lactose was determined by copper reduction method following the procedure of Pearson's composition and analysis of food (Ronalds Kirk and Ronald Sawyer, 1991).

\section{Results and Discussion}

It was observed from Table I that raw cow's milk covered with water hyacinth leaves $\left(T_{1}\right)$ and keeping at open space with stirring $\left(\mathrm{T}_{2}\right)$ were in good condition for 5 hours. On the other hand raw milk under ice-cold treatment

Table I. Shelf-life of different treated milk at $\pm 28^{\circ} \mathrm{C}$ by physical observation.

\begin{tabular}{c|c|c}
\hline Milk taken (c.c) & Treatments & Shelf-life (hrs) \\
\hline 500 & $\mathrm{~T}_{1}$ & 5 \\
500 & $\mathrm{~T}_{2}$ & 5 \\
500 & $\mathrm{~T}_{3}$ & 8 \\
\hline
\end{tabular}

$\left(\mathrm{T}_{3}\right)$ was in good condition for 8 hours as assessed from physical observation of casein separations observed after heating the treated milk which was considered as a parameter of milk deterioration.

It is seen from the Table II. that milk treated with $0.05 \% \mathrm{H}_{2} \mathrm{O}_{2}$ reached maximum shelf life of 11 hours whereas milk treated with the gradual increase in concentration from $0.1 \%$ to $0.5 \%$ showed lower shelf life of 9-10 hours. So it is evident that high concentration of $\mathrm{H}_{2} \mathrm{O}_{2}$ has no significant effect to increase storage period.

Table II. Storage condition of raw cow's milk after chemical treatment with hydrogen peroxide at different concentration at $\pm 28^{\circ} \mathrm{C}$

\begin{tabular}{c|c|c}
\hline $\begin{array}{c}\text { Milk taken } \\
\text { (c.c) }\end{array}$ & $\begin{array}{r}\text { Concentration } \\
\text { of } \mathrm{H}_{2} \mathrm{O}_{2} \text { (\%) }\end{array}$ & $\begin{array}{c}\text { Shelf-life of treated } \\
\text { milk (hours) }\end{array}$ \\
\hline 500 & 0.05 & 11 \\
500 & 0.1 & 10 \\
500 & 0.2 & 09 \\
500 & 0.3 & 09 \\
500 & 0.4 & 10 \\
500 & 0.5 & 10 \\
\hline
\end{tabular}

So less concentration (0.05\%) is the selected concentration for preserving milk and further study was conducted with this concentration. $\mathrm{pH}$ was recorded in both the control and treated sample and the results were shown in 
Table III. $\mathrm{pH}$ recorded during storage at $\pm 8^{\mathrm{O}} \mathrm{C}$

\begin{tabular}{c|c|c|c|c|c}
\hline $\begin{array}{c}\text { Days of } \\
\text { storage }\end{array}$ & $\begin{array}{c}\mathrm{pH} \text { of control } \\
\text { sample }\end{array}$ & $\begin{array}{c}\mathrm{pH} \text { of chemically } \\
\text { treated sample }\end{array}$ & $\begin{array}{c}\text { Days of } \\
\text { storage }\end{array}$ & $\begin{array}{c}\mathrm{pH} \text { of control } \\
\text { sample }\end{array}$ & $\begin{array}{c}\mathrm{pH} \text { of chemically } \\
\text { treated sample }\end{array}$ \\
\hline 1st & 7.55 & 7.35 & 12 th & - & 6.85 \\
2nd & 7.33 & 7.35 & 13 th & - & 6.88 \\
3rd & 7.30 & 7.27 & 14 th & - & 6.80 \\
4th & 7.80 & 7.10 & 15 th & - & 6.77 \\
5th & 6.40 & 7.08 & 16 th & - & 6.71 \\
6th & - & 7.05 & 17 th & - & 6.70 \\
7th & - & 7.04 & 18 th & - & 6.68 \\
8th & - & 7.01 & 19 th & - & 6.61 \\
9th & - & 7.00 & 20 th & - & 6.58 \\
10th & - & 6.99 & 21 th & - & 6.40 \\
11th & - & 6.91 & & & \\
\hline
\end{tabular}

Table IV. Proximate composition of sample after chemical treatment $0.05 \% \mathrm{H}_{2} \mathrm{O}_{2}$

\begin{tabular}{c|c|c|c|c|c}
\hline Day & Moisture (\%) & Ash (\%) & Protein (\%) & Fat (\%) & Lactose (\%) \\
\hline 1st & $88.36^{\mathrm{a}}$ & $0.69^{\mathrm{a}}$ & $3.03^{\mathrm{a}}$ & $4.03^{\mathrm{ab}}$ & $4.02^{\mathrm{a}}$ \\
3rd & $88.35^{\mathrm{a}}$ & $0.68^{\mathrm{a}}$ & $3.02^{\mathrm{a}}$ & $4.00^{\mathrm{a}}$ & $4.01^{\mathrm{a}}$ \\
6th & $88.35^{\mathrm{a}}$ & $0.67^{\mathrm{a}}$ & $3.02^{\mathrm{a}}$ & $4.02^{\mathrm{a}}$ & $4.01^{\mathrm{a}}$ \\
9th & $88.34^{\mathrm{a}}$ & $0.65^{\mathrm{a}}$ & $3.01^{\mathrm{a}}$ & $4.02^{\mathrm{a}}$ & $4.03^{\mathrm{ab}}$ \\
12th & $88.34^{\mathrm{a}}$ & $0.65^{\mathrm{a}}$ & $3.03^{\mathrm{a}}$ & $4.01^{\mathrm{a}}$ & $4.00^{\mathrm{a}}$ \\
15th & $88.34^{\mathrm{a}}$ & $0.65^{\mathrm{a}}$ & $3.01^{\mathrm{a}}$ & $4.00^{\mathrm{a}}$ & $4.01^{\mathrm{a}}$ \\
18th & $88.32^{\mathrm{a}}$ & $0.62^{\mathrm{a}}$ & $3.02^{\mathrm{a}}$ & $4.03^{\mathrm{ab}}$ & $4.02^{\mathrm{a}}$ \\
\hline
\end{tabular}

Table III. From Table III it is observed that on the 5th day of storage the control sample deteriorated when $\mathrm{PH}$ dropped down from 7.55 to 6.40 . On the other hand sample treated with (0.05\% concentration) $\mathrm{H}_{2} \mathrm{O}_{2}$ required 21st day of storage to reach the same $\mathrm{pH}$ level.
So it can be concluded from the results of the table that the control sample was in good condition for 5 days of storage whereas chemically treated sample was in good condition for 20 days at the same storage condition. 
Table V. Comparative bacteriological counts of raw milk, treated milk and formulated treated product

\begin{tabular}{|c|c|c|c|c|}
\hline Sample & $\begin{array}{c}\text { Incubation } \\
\text { period (in hrs) }\end{array}$ & $\begin{array}{c}\text { Mean SPC } \\
\log _{10} \mathrm{cfu} / \mathrm{ml}\end{array}$ & $\begin{array}{l}\text { Total Coliform } \\
\text { MPN/100ml }\end{array}$ & $\begin{array}{c}\text { E. coli } \\
\text { MPN/100ml }\end{array}$ \\
\hline $\mathrm{C}$ & 0 & 8.56 & $>2400$ & $>2400$ \\
\hline $\mathrm{C}$ & 24 & 8.21 & , & ” \\
\hline $\mathrm{C}$ & 48 & 8.69 & ", & ” \\
\hline $\mathrm{C}$ & 72 & 8.13 & ", & " \\
\hline $\mathrm{C}$ & 96 & 8.47 & , & , \\
\hline $\mathrm{C}$ & 120 & 8.47 & " & ” \\
\hline $\mathrm{T}$ & 0 & 8.02 & , & ” \\
\hline $\mathrm{T}$ & 48 & 8.89 & ", & " \\
\hline $\mathrm{T}$ & 96 & 8.83 & " & " \\
\hline $\mathrm{T}$ & 144 & 8.23 & , & ” \\
\hline $\mathrm{T}$ & 192 & 8.37 & , & , \\
\hline $\mathrm{T}$ & 240 & 8.47 & , & " \\
\hline $\mathrm{T}$ & 336 & 8.46 & , & ” \\
\hline $\mathrm{T}$ & 432 & 8.48 & , & , \\
\hline $\mathrm{T}$ & 480 & 8.45 & ", & " \\
\hline Formulated & Kheer & $<10$ & Nil & Nil \\
\hline product & Halwa & $<10$ & Nil & Nil \\
\hline
\end{tabular}

SPC $=$ Standard plate count, $\mathrm{C}=$ Control sample, $\mathrm{T}=$ Treated with hydrogen peroxide

Means with the same letters are not different from one another at $5 \%$ significance level (Steel and Terrie, 1960). From the statistical analysis of the data which is shown in Table IV it can be concluded that almost all the nutritional values of the treated samples remain unchanged during the storage period.

Microbiological counts were determined in the treated sample in every alternate day while daily counts were made with control sample (Table V). The table shows no significant variation in the mean SPC (log 8.02-8.89), Total Coliform and E.coli countthroughout the study period. However product was prepared from treated and stored milk of 21 days storage was completely free from any organism of fecal and non-fecal origin. 
Storage period of milk as was determined by three different treatments $\mathrm{T}_{1}, \mathrm{~T}_{2}, \mathrm{~T}_{3}$ at $\pm 28^{\mathrm{O}} \mathrm{C}$ showed that treatment of raw cow's milk $\left(\mathrm{T}_{3}\right)$ with ice-cold water had better shelf life (8 hours) than those of other two treatments $\mathrm{T}_{1}$ and $\mathrm{T}_{2}$ (5 hours each). When milk was treated with hydrogen peroxide and stored at room temperature $\pm 28^{\circ} \mathrm{C}$ with different concentration such as $0.05 \%, 0.1 \%, 0.2 \%$, $0.3 \%, 0.4 \%, 0.5 \%$ it was observed that increased concentration of hydrogen peroxide from $0.05 \%$ to $0.5 \%$ had no significant effect on the storage life milk as determined by physical parameter (Table II). From the experiments so far done, $0.05 \%$ concentration is the selected concentration for keeping the quality of milk. The above results are in agreement with the reported observation that hydrogen peroxide treated milk (at 300-800 ppm) equivalent has storage period of 7 to 8 hours at $30^{\circ} \mathrm{C}$ Food Laboratory News Letter (1987).

Roundy also reported almost similar result (Roundy 1961). Ambadkar et al. found that the addition of hydrogen peroxide for milk significantly increased the shelf-life without affecting its freshness. The concentration of 300ppm hydrogen peroxide preserved the cow's milk for 18 hours (Ambadker and Lembre, 1961). The literature value correlates more or less to our present findings (milk treated with $0.05 \%$ hydrogen peroxide showed storage period of 11 hours at $\pm 28^{\circ} \mathrm{C}$.
In the present study $\mathrm{pH}$ of the control and treated sample were 7.55 and 7.35 respectively (Table III) which gradually dropped down with the increase of storage period. The increased value might be due to variation in breed, animal to animal variability, age, state of location, season of the year, the fed time, time of milking, period of time between milking etc. The physiological conditions of the cow whether it is receiving drugs and so on, all these factors also affect the quality of milk (Norman et al. 1996). But the rate of dropping of the $\mathrm{pH}$ is different which clearly indicated the shelf life of milk.

After analysis of the proximate composition of nutrient contents in every two days interval it was found that the nutritive value has not been affected in hydrogen peroxide treated milk. Similar results were also reported by Margaret E.Gregory et. al in 1961.

From the microbiological point of view (Table V) results of the study concludes that initial microbiological quality of cow's milk in raw condition were not hygienically good. But after heat treatment and with the preparation of other milk based food products from this milk such as "kheer" and "halawa" didn’t show any microbiological load (Table V). As the experimental milk sample was collected randomly from local market, the initial microbiological load maybe due to dirty milk sampling cans and milking 
methodology. Another significant observation of this study is that there is no increase of microbiological load in the treated sample. So hydrogen peroxide can be used as an effective, low cost chemical preservative for storage of milk sample.

\section{Conclusion}

The development of this low cost process for the preservation of cow's milk in raw condition can be used efficiently instead of expen sive cooling system. This is expected to save daily loss of several liters of milk before and during marketing. The other important aspect of this method is that no energy is needed in this system.

\section{References}

A.O.A.C (1984) Official methods of analysis. 12th edition. Association of Official Agricultural Chemists, Washington D.C. U.S.A 281: 284.

Ambadker, R K. Lembre, A F. (1961) A study of hydrogen peroxide as a preservative for enhanching the keeping quality of milk, Journal Maharastrea Agri University. 16(2) 284-250.

APHA (1985) Standard Methods for the examination of water and water. 16th edition, American public health Association, Washington, DC, 789-805.
Food Laboratory News Letter (1987) No1023.

Grindrod, J. and Nickorson, TA. Changes in milk protein treated with hydrogen peroxide $J$. Dairy science No 1, 50 : 142.

Margarat, E.G. Henry, M.K. Kon, SK. Porter, JWD. and Thomson, SY. (1961) The effect of hydrogen peroxide in the nutritive value of milk, J. Dairy Science 28 : 177.

Murris, A.J. (1948) A comparative study of the treatment of the milk and hydrogen peroxide and pasteurization. Report no. 9, Utah state college, logan, Utah 1230.

Norman, N. Potter. Joseph. Hotchkiss, H. (1996) Food Science, 5th Ed. 280.

Pearson's composition and Analysis of food. (1991) Ronalds Kirk and Ronald Sawyer, 9th edition 537.

Report on the use of hydrogen peroxide and other preservatives in milk. (1954) Food and Agriculture Organization, United Nations 57/86555.

Rosell, J M. Daga, C. Fernaudez, (1959) New test on the bacteriostatic effect on hydrogen peroxide added to raw milk and its bactericide effect in connection with the pasteurization and sterilization of milk. Dairy Science Abstract 8(21) : 356.

Rosell, J M. (1961) Hydrogen peroxide - cata- 
logue method for treatment of milk, Journal of Canadian Dairy and Ice-Ocean

50.

Roundy, Z D. (1961) Treatment of raw milk with hydrogen peroxide. Milk produc $J$. 7(21) : 52 .

Sayem, A.Z.M. (1998) Present status of milk and milk products of Bangladesh vis- a- vis imported milk powder. Proceedings of the seminar on processing and preservation of food and fruit production of Bangladesh. June 29 .
Statistical year book of Bangladesh 19th Edition (1998) 603.

Steel, R.G.D. Torrie, J.H. (1960) Principle and procedure of statistics, Mc. Graw Hill Book Co. Inc. New York 109.

Venden Berg, JeT. (1985) Dairy Technology in tropics and subtropics. Pudoc Wageningen 155.

Yapp. Nevens. Dairy Cattle 4th Ed. (1955) 304.

Received : April 13, 2006;

Accepted : August 13, 2007 